\title{
Przedstawienia Ducha Świętego na ikonach bizantyjskich i ruskich. Kanon ikonograficzny a dogmat teologiczny
}

Już na soborze nicejskim z 325 roku $^{1}$ podkreślono wiarę w Trzy Osoby Boskie: Boga Ojca, Syna Bożego i Ducha Świętego². Niemniej jednak wówczas w większym stopniu wypowiedziano się na temat Ojca i Syna niż Ducha Świętego. Właściwie tylko zaznaczono Jego istnienie i nie określono Jego przymiotów. Kontrowersje dotyczące boskości Ducha Świętego doprowadziły do zwołania na rok 381 soboru w Konstantynopolu, który ostatecznie miał rozstrzygnąć tę kwestię. Wówczas w aktach soborowych pojawiły się dodatkowe określenia odnośnie do Trzeciej Osoby Trójcy $^{3}$. Napisano wtedy: „Wierzymy [...] w Ducha Świętego, Pana i Ożywiciela, który od Ojca pochodzi, którego należy czcić i wielbić wraz z Ojcem i Synem, który przemawiał przez proroków" "4. Podkreślono także Jego rolę w akcie Wcielenia, a do

\footnotetext{
${ }^{1}$ Por. I. Ortiz de Urbina, El Simbolo Niceno, Madrid 1947; M. F. Wiles, A Textual Variant in the Creed of the Council of Nicaea, Studia Patristica 26, Leuven 1993.

${ }^{2}$ Sobór Nicejski I (325), Wyznanie wiary 318 Ojców, [w:] Dokumenty soborów powszechnych, t. 1, red. A. Baron, H. Pietras, Kraków 2002, s. 24-25: „Credimus in unum deum patrem omnipotentem visibilium et invisibilium factorem. Et in unum dominum Iesum Chrustum filium dei, natum de patre, hoc est de substantia patris, deum de deo, lumen de lumine, deum verum de deo vero, natum non factum, unius substantiae cum patre, quod Graeci dicunt homousion, per quem omnia facta sunt sive quae in celo sive quae in terra; qui propter nos homines et propter nostram salutem descendit, incarantus est, homo factus est, passus est et resurrexit tertia die, ascendit in caelos venturus iudicare vivos et mortuos. Et in spiritum sanctum".

${ }^{3} \mathrm{Na}$ temat pierwszych soborów por. G. L. Dossetti, Il Simbolo di Nicea e di Constantinopli. Edizione critica, Roma 1967; J. M. Mansi, Sacrorum Conciliorum Nova et Amplissima Collectio, Paris 1901; E. Schwartz, Acta Conciliorum Oecumenicorum, Berolini et Lipsiae 1927-1932; P. P. Joannou, Les canons des conciles oecuméniques, Grottaferrata-Roma 1962; G. Alberigo, G. L. Rossetti, P. P. Joannou, C. Leopardi, P. Prodi Conciliorum Oecumenicorum Decreta, Colonia 1991; J. N. D. Kelly, Early christian Creeds, London 1950; H. J. Sieben, Die Konzilsidee der Alten Kirche, Padeborn 1979.

${ }^{4}$ Sobór Konstantynopolitański I (381), Wyznanie wiary 150 Ojców, [w:] Dokumenty soborów..., s. 68: „Credimus [...] spiritus sanctum, dominum et vivificatorem, ex patre procedentem, cum patre et filio coadorandum et conglorificandum, qui locutus est per prophetas".
} 
opisu Syna Bożego dodano, iż ,przyjął ciało za sprawą Ducha Świętego z Maryi Dziewicy i stał się człowiekiem"s.

Należy zauważyć, że zdania odnoszące się do Trzeciej Hipostazy Trójcy z konieczności musiały być zawarte $\mathrm{w}$ aktach konstantynopolitańskich. W tym czasie okazało się to bardzo ważne, gdyż związane było z odpieraniem zarzutów tzw. duchoburców (pneumatomachów) ${ }^{6}$ nieuznających boskości Ducha Świętego. Z tego też względu sobór w Konstantynopolu zdecydowanie potępił tych, którzy głosili błędy odnośnie do dogmatu trynitarnego, m.in. sabelian ${ }^{7}$, marcelian $^{8}$, fotynian ${ }^{9}$.

Stąd też zaistniała konieczność udowodnienia, że Trzecia Osoba Trójcy Świętej jest także Bogiem. Takie zadanie postawili przed sobą tacy teolodzy jak Grzegorz z Nazjanzu, Grzegorz z Nyssy, Ambroży z Mediolanu czy Bazyli Wielki. ${ }^{10}$.

Na soborze w Konstantynopolu używano słowa homooúsios, co świadczy o tym, że pod względem istoty zarówno Syn, jak i Duch Święty są równi Ojcu. Boskość Trzeciej Osoby Trójcy została potwierdzona, ale nadal otwarta pozostawała sprawa odnośnie do Jej pochodzenia, która stała się kluczowa w sporach między grekami a łacinnikami. Podczas gdy na Wschodzie trzymano się ściśle credo ustalonego

${ }^{5}$ Tamże, s. 68: „[...] et incarnatus est de spiritu sancto et Maria virgine humanatus est”.

${ }^{6}$ Por. Dokumenty soborów powszechnych..., s. 69, przypis 3. Duchoburcy zwani macedonianami (od biskupa Konstantynopola Macedoniusza) wysuwali z arianizmu skrajne wnioski, uznali bowiem podległość Syna Ojcu, a Ducha Świętego Synowi. Nie uznawali boskości Trzeciej Osoby Trójcy, lecz traktowali Ją jako Ducha służącego Bogu. Por. B. Kumor, Historia Kościoła, t. 1, Lublin 2003, s. 148. „Duchoburcy” traktowali Ducha Świętego jako moc Boga, nieposiadającą jednak własnej osoby. W tym znaczeniu terminu tego używał także Atanazy Wielki. Por. Dokumenty soborów powszechnych..., s. 71, przypis 7. Por. H. G. Opitz, Athanasius Werke III, 1, Berlin-Leipzig 1934. Atanazy był bezkompromisowy, jeśli chodzi o zwalczanie argumentów macedonian. Przeciwko nim wypowiedział się też synod „wyznawców” w Aleksandrii (362), który przyjął, iż Duch Święty jest Osobą tak jak Ojciec i Syn oraz że posiada taką samą jak Oni istotę i naturę, jest więc Im równy. Por. B. Kumor, Historia ..., dz. cyt., s. 149.

${ }^{7}$ Sabeliusz (II w.) stworzył tzw. monarchianizm modalistyczny, według którego Bóg jest tylko Jedną Osobą ukazującą różne swoje oblicza, czyli objawiającą się na różne sposoby (modi). Oznacza to, iż Jedna Boska Osoba pojawia się się albo jako Ojciec, albo jako Syn, albo też jako Duch Święty. Por. Dokumenty soborów powszechnych ..., s. 71, przypis 8. Bóg jako Stwórca pozostaje niepodzielną monadą. Może jednak wkraczać w historię świata i rozszerzać zasięg swego działania, co związane jest z przyjmowaniem przez Niego różnych postaci. Na ziemi narodził się jako Syn, a później zstąpił na ludzi jako Duch-Święty. Por. J. N. D. Kelly, Początki doktryny chrześcijańskiej, Warszawa 1988, s. 99.

${ }^{8}$ Marceli z Ancyry († 374) był zwolennikiem jedności w Bogu bez rozróżnienia w Nim Osób (hipostaz). Por. Dokumenty soborów powszechnych ..., s. 71, przypis 9. W czasach ostatecznych Syn Boży, czyli Logos, oraz Duch Święty powrócą do Monady, czyli pierwotnej Jedności.

${ }^{9}$ Fotyn z Sirmium (†376), uczeń Marcelego zakładał jedność Bożej Monady, odrzucał realne istnienie Osób Boskich. Por. Dokumenty soborów powszechnych..., s. 71, przypis 10.

${ }^{10}$ Por. Bazylius, De Spiritu Santo, Patrologiae Cursus Completus. Series Graeca 32, ed. J. P. Migne, Paris 1886; B. Pruche, Basile de Césarée: Sur le Saint-Esprit, Sources Chrétiennes 17bis, Paris 1947; Bazyli Wielki, O Duchu Świętym, tłum. A. Brzóstkowska, Warszawa 1999; Bazyli Wielki w swoich dziełach teologicznych zwalczał poglądy arian i duchoburców. Por. B. Kumor, Historia ..., dz. cyt., s. 152. Na temat Bazylego por. A. Angeli, Basilio di Cesarea, Milano 1968; P. Scazzoso, Introduzione alla ecclesiologia di san Brasilio, Milano 1975; J. Riviere, Saint Basile: Histoire de sa vie et extraits de ses écrits, Lille 1850; P. Allard, Saint Basile (329-379), Paris 1903. 
w Konstantynopolu w 381 roku, gdzie napisano, iż Duch Święty pochodzi od Ojca, to na Zachodzie z czasem coraz bardziej upowszechniała się formuła mówiąca, że Trzecia Osoba Trójcy pochodzi zarówno od Ojca, jak i od Syna, o czym świadczy dodatek „od Syna” (Filioque) ${ }^{11}$. W aktach III synodu toledańskiego z 589 roku, w kanonie 2. o Duchu Świętym napisano: „Należy głosić, że pochodzi (procedere) od Ojca i od Syna, i z Ojcem i Synem jest jednej istoty (substantia)" ${ }^{12}$. Wyrażenia Filioque na Zachodzie używał Ambroży z Mediolanu, według którego Trzecia Osoba Trójcy Świętej nie może się oddzielić od Ojca i Syna i pochodzi od Nich razem ${ }^{13}$.

Oczywiście trzeba zaznaczyć, że na samym początku różnice między wschodnią a zachodnią teologią nie były aż tak wyraźne, bo wszędzie zgodnie uznawano, że zarówno Ojciec, jak i Syn są źródłem dla istnienia Trzeciej Hipostazy Trójcy. Niemniej jednak istniały dwa podejścia do tej kwestii. Teolodzy wschodni nie chcieli zmieniać formuły credo konstantynopolitańskiego i trzymali się ściśle jego litery. Za bardziej słuszne uznali oni przyjęcie stwierdzenia, że Duch Święty pochodzi: „od Ojca przez Syna”, podczas gdy pisarze zachodni używali formuły: „od Ojca i Syna" "14. Myśl wschodnią zdawał się dobrze rozumieć Hilary z Poitiers, który chociaż działał na Zachodzie, to jednak stwierdzał, że Duch Święty pochodzi od Ojca przez jedynego Jego Syna ${ }^{15}$. Nawet Augustyn z Hippony, wielki teolog zachodni zaakcentował główną rolę Ojca we współistotnej Trójcy. Według niego Duch Święty pochodzi od Ojca jako od głównej zasady, czyli źródła. Niemniej jednak jeśli się uzna, że dar Ojca dla Syna jest bezczasowy i są Oni wspólistotni, to należy przyjąć, że Duch Święty pochodzi w komunii (czyli wspólnie) od Ojca i Syna ${ }^{16}$.

Na temat Ducha Świętego wypowiadało się wielu ojców Kościoła, niemniej jednak poglądy teologa z Hippony w najpełniejszy sposób odzwierciedlają naukę przyjętą przez Kościół. Autor ten uznaje w pełni Ducha Świętego za Osobę, która ma swoją rolę w Boskiej Trójcy. Według Augustyna jest On Duchem i Ojca, i Syna, chociaż nie jest zrodzony ani przez Ojca, ani przez Syna, ani przez Nich razem ${ }^{17}$.

\footnotetext{
${ }^{11} \mathrm{Na}$ temat Filioque por. M. D. Knowles, D. Obolensky, Historia Kościoła, t. 2, 600-1500, thum. R. Turzyński, Warszawa 1988, s. 83.

${ }^{12}$ J. D. Masi, Sacrorum Conciliorum nova collectio, t. 9, Paryż-Lipsk 1921-1927, s. 981D. ,a Patre et a Filio procedere et cum Patre et Filio unius esse substantiae".

${ }^{13}$ Por. Ambrosius, De Spiritu Sancto Libri Tres, I, 11, 120, Patrologiae Cursus Completus. Series Latina (dalej: PL), ed. J. P. Migne, Paris 1845, 16, 733: „Spiritus quoque sanctus cum procedit a Patre et Filio, non separatur a Patre, non separatur a Filio".

${ }^{14}$ Por. M. D. Knowles, D. Obolensky, Historia Kościoła, s. 106.

${ }^{15}$ Por. Hilarius Pictaviensis, De Trinitate, XII, PL 10, 472: „Patrem scilicet te nostrum, Filium tuum una tecum adorem: sanctum spiritum tuum, qui ex te per unigenitum tuum est, promerear."

${ }^{16}$ Por. Augustinus, De Trinitate, XV, 26, 47, PL 42, 1095: „et Spiritus Sanctus de Patre principaliter, et ipso sine ullo temporis intervallo dante, communiter de utroque procedit”; Św. Augustyn, O Trójcy Świętej, tłum. M. Stokowska, Kraków 1996, s. 521.

${ }^{17}$ Por. Augustinus, De Trinitate, I, 5, 8, PL 42, 824: „Movet etiam quomodo spiritus sanctus in trinitate sit, quem nec pater nec filius nec ambo genuerint, cum sit spiritus patris et filii”, św. Augustyn, O Trójcy Świętej, dz. cyt., s. 32.
} 
To Duch prawdy oraz wystarczające źródło szczęścia dla ludzi z tego względu, że nie można Go oddzielić od Ojca i Syna ${ }^{18}$. Trzecia Osoba Trójcy to prawdziwy Bóg, a nie stworzenie, gdyż jest równa Ojcu i Synowi. Ponieważ Trójca to jedność wszystkich Osób, dlatego Duch Święty jest współistotny i współwieczny z pozostałymi Osobami ${ }^{19}$ oraz należy Mu służyć jako Bogu zgodnie ze słowami Apostoła: „Bo prawdziwie obrzezani jesteśmy my, służący Duchowi Bożemu” (Flp 3, 3 ) ${ }^{20}$.

Augustyn podkreśla również fakt, że Duch Święty zamieszkuje w ludzkim ciele niczym w świątyni, o czym mówił św. Paweł: „Czyż nie wiecie, że ciała wasze są w was świątynią Ducha Świętego, którego macie od Boga?” (1 Kor 6, 19)21. Jeżeli zaś członki Chrystusowe, czyli ciała ludzkie stanowią świątynię Ducha Świętego, świadczy to o tym, iż nie może być On stworzeniem. Zaś ludzie, oddając Mu swe ciała jako świątynie, w ten sposób oddają Mu cześć należną samemu Bogu ${ }^{22}$.

W tym samym czasie, kiedy ustalano dogmaty teologiczne, kształtowały się też kanony obowiązujące w sztukach plastycznych. Jednak ikonopisarze od samego początku zmagali się z trudnościami związanymi z wyobrażaniem Ducha Świętego, i to zarówno dotyczącymi epifanicznych wyobrażeń całego Trójosobowego Boga, jak i ikon ukazujących Bogurodzicę i Chrystusa. Nie istnieją przecież jakieś bezpośrednie informacje w Piśmie Świętym mówiące o tym, w jakiej postaci należy przedstawiać Trzecią Hipostazę Trójcy. Duch Święty pozostaje niewidoczny, a tylko skutki Jego działania zaświadczają, iż jest On naprawdę obecny ${ }^{23}$. Na ikonach nigdy nie jest ukazywany samotnie, lecz razem z pozostałymi Osobami Trójcy. Trudno bowiem by było ukazać w jakiejś konkretnej formie tylko przejawy Jego działania, czyli owoce Ducha, jakie wymienia św. Paweł ${ }^{24}$. Podczas gdy brak ikony Boga Ojca

${ }^{18}$ Por. Augustinus, De Trinitate, I, 8, 18, PL 42, 832: „Propter hoc aliquando ita loquitur de spiritu sancto tamquam solus ipse sufficiat ad beatitudinem nostram; et ideo solus sufficit quia separari a patre et filio non potest", Św. Augustyn, O Trójcy Świętej, dz. cyt., s. 47.

${ }^{19}$ Por. Augustinus, De Trinitate, I, 6, 13, PL 42, 827: „Quod si non creatura, non tantum deus (nam et homines dicti sunt dii), sed etiam verus deus. Ergo patri et filio prorsus aequalis et in trinitatis unitate consubstantialis et coaeternus", Św. Augustyn, O Trójcy Świętej, dz. cyt., s. 38.

${ }^{20}$ Augustinus, De Trinitate, I, 6, 13, PL 42, 827-828: „Porro si tali servitute creaturae servire prohibemur quandoquidem dictum est: Dominum deum tuum adorabis et illi soli servies unde et apostolus detestatur eos qui colverunt et servierunt creaturae quam creatori, non est utique creatura spiritus sanctus cui ab omnibus sanctis talis servitus exhibetur dicente apostolo: Nos enim sumus circumcisio, spiritui dei servientes, quod est in graeco latrevontes", Św. Augustyn, O Trójcy Świętej, dz. cyt., s. 38.

${ }^{21}$ Por. Augustinus, De Trinitate I, 6, 13, PL 42, 828: „Nescitis quia corpora vestra templum in vobis est spiritus sancti quem habetis a deo?”, Św. Augustyn, O Trójcy Świętej, dz. cyt., s. 39.

${ }^{22}$ Por. Augustinus, De Trinitate, I, 6, 13, PL 42, 828: „Alio enim loco dicit: Corpora vestra membra sunt Christi. Si autem quae membra sunt Christi templum est spiritus sancti, non est creatura spiritus sanctus, quia cui corpus nostrum templum exhibemus necesse est ut huic eam servitutem debeamus qua non nisi deo serviendum est, quae graece appellatur $\lambda \alpha \tau \rho \varepsilon i ́ \alpha$ latreia", Św. Augustyn, O Trójcy Świętej, dz. cyt., s. 39.

${ }^{23}$ Por. L. Balter, Pneumatologia w ikonie, [w:] Chrystus wybawiajacy. Teologia świętych obrazów, red. A. Napiórkowski, Kraków 2003, s. 75.

${ }^{24}$ Ga 5, 22-23: „Owocem Ducha jest: miłość, radość, pokój, cierpliwość, uprzejmość, dobroć, wierność, łagodność, opanowanie. Przeciw takim [cnotom] nie ma Prawa”. 
można wytłumaczyć Jego transcendencją wobec świata, to trudno przyjąć takie uzasadnienie, jeśli chodzi o przedstawienia Ducha Świętego. Chociaż nie wcielił się On w żadną osobę, to jednak został posyłany z misją na ziemię i realnie działa w świecie ${ }^{25}$, nie można więc mówić o Jego transcendencji wobec rzeczywistości. Duch Święty na ikonach przeważnie nie jest ukazywany hipostatycznie z powodu braku Jego hipostatycznego objawienia się. Dlatego ukazywano Go pod postacią niższego stworzenia (gołębica) czy też materii nieożywionej (języki ognia) ${ }^{26}$.

Już we wczesnej sztuce chrześcijańskiej Duch Święty wyobrażany był jako gołębica (columba). Do Trzeciej Osoby odnosiło się określenie Spiritus Sanctus, które często umieszczano na sarkofagach i dotyczyło ono także duszy sprawiedliwej ${ }^{27}$. Gołębica pojawia się również w Starym Testamencie w opisie potopu. Noe wypuścił z arki gołębicę, która wróciła z powrotem do arki z gałązką oliwną, co świadczy o tym, że zwiastowała pokój. Zauważa się tu analogię z gołębicą Ducha Świętego, która zesłana do obmytego kąpielą ludzkiego ciała ofiarowuje mu pokój ${ }^{28}$.

Teolodzy oraz artyści zastanawiali się, jakie jest prawdziwe i rzeczywiste oblicze Ducha Świętego i w jaki sposób można Go przedstawiać. Podczas gdy Ojca w pełni objawia Syn Boży, a Syna w pełni objawia Duch Święty zesłany podczas Pięćdziesiątnicy, to otwarte pozostaje pytanie, kto objawi w zupełnej pełni Trzecią Hipostazę Trójcy. W doskonały sposób Ducha Świętego może objawić stworzenie ludzkie, lecz tylko takie, które pozostaje doskonale przeniknięte Duchem Świętym i jest przezroczyste na Jego działanie ${ }^{29}$. Mowa jest tutaj o Maryi, która bezwarunkowo przyjmuje wolę Boga. Jednak w pewnym sensie można też mówić o pośrednim Jego przedstawieniu w innych osobach teoforycznych (czyli „,noszących Boga”)

\section{Bogurodzica ikoną Ducha Świętego}

Maryja, chociaż była człowiekiem, to jednak całkowicie i w sposób doskonały zespoliła się z Duchem Świętym ${ }^{31}$, i nawet w pewnym sensie Go uosabia ${ }^{32}$. To właśnie

${ }^{25}$ Por. S. Bułgakow, Ikona i kult ikony, tłum. H. Paprocki, Bydgoszcz 2002, s. 85.

${ }^{26}$ Por. tamże, przyp. 96, s. 84.

${ }^{27}$ Por. A. Nowowiejski, Wyktad liturgiki Kościoła katolickiego, t. 1/2, Warszawa 1893, s. 570.

${ }^{28}$ Por. tamże, s. 585. Również św. Jan z Damaszku widział podobieństwo między gołębicą Ducha Świętego a gołąbkiem z gałązką oliwną, który stał się znakiem pokoju po zakończeniu potopu. Por. św. Jan Damasceński, De fide orth., III, 16; podaję za: P. Evdokimov, Sztuka ikony. Teologia piękna, tłum. M. Żurowska, Warszawa 1999, przyp. 9, s. 245.

${ }^{29}$ Por. L. Balter, Pneumatologia ..., s. 77.

${ }^{30}$ Por. S. Bułgakow, Ikona ..., s. 85.

${ }^{31}$ W Bogurodzicy nastąpiło zjednocznie Ducha Świętego ze stworzoną ludzką hipostazą. Oczywiście w rzeczywistym znaczeniu Trzecia Hipostaza Trójcy nie wciela się w człowieka, ale objawia się w człowieku, czyli w Maryi, która jest Pneumatoforą. Por. S. Bułgakow, Prawosławie. Zarys nauki Kościoła prawosławnego, thum. H. Paprocki, Białystok-Warszawa 1992, s. 134-135; podaję za: L. Balter, Pneumatologia ..., s. 79.

${ }^{32}$ Istnieją też hipotezy mówiące, że Duch Święty ,wcielił się” w Maryję. Por. L. Boff, Il volto Materno di Dio, Brescia 1981; S. Gręś, Relacja: „Duch Święty-Maryja” we wspótczesnej teologii 
w Bogurodzicy nastąpiło zjednoczenie Ducha Świętego ze stworzoną ludzką hipostazą. Jednak trzeba dodać, że w rzeczywistym znaczeniu Trzecia Osoba Trójcy nie wciela się w człowieka, ale objawia się w człowieku, czyli w Maryi będącej Pneumatoforą ${ }^{33}$.

Według Maksymiliana Kolbego można uznać, że w pewnym sensie Maryja jest wcieleniem Trzeciej Hipostazy Trójcy ${ }^{34}$. Autor podkreśla, że Duch Święty żyje w Niej od pierwszej chwili istnienia i przez całe Jej istnienie ${ }^{35}$, co znaczy, że od samego początku była Ona Jego Oblubienicą. Mamy tu zatem do czynienia ze zjednoczeniem osobowym między Dawcą łaski a Tą, która przyjmuje łaskę ${ }^{36}$. Występuje tu analogia do Wcielenia Drugiej Osoby Boskiej ${ }^{37}$, ale tak naprawdę chodzi raczej o quasi-inkarnację Trzeciej Osoby Trójcy w Maryi. Można więc mówić o wewnętrznym związku i zjednoczeniu woli Maryi z wolą Boga, na którą Ona całkowicie się zgodziła ${ }^{38}$.

Istotą Trzeciej Osoby Trójcy jest świętość, a już samo Jej imię wyraża to, że stanowi Ona świętość całego Trójosobowego Boga ${ }^{39}$. Tak jak Duch Święty określany jest jako „Cały Święty” (Panagion), tak i Bogurodzicy przysługuje tytuł Panagia - „Cała Święta" ${ }^{\prime 40}$. Maksymilian Kolbe widział analogię między tytułem, jaki przysługuje Maryi a imieniem własnym Ducha Świętego. Według niego określenie Niepokalane Poczęcie to synonim imienia Ducha Świętego. Duch (od łac. Spiritus) oznacza Tchnienie, a także „Poczęcie” (czyli pochodzenie) ${ }^{41}$. Maksymilian uznał, że tylko Bogurodzica może być doskonałym mieszkaniem dla Odwiecznego Niepokalanego Poczęcia, czyli Ducha Świętego ${ }^{42}$. To On jako „Niepokalane Poczęcie niestworzone” uznaje za swoje autentyczne odbicie na ziemi „Niepokalane Poczęcie stworzone”, czyli Maryję ${ }^{43}$.

katolickiej (1965-2000), Niepokalanów 2001, s. 184n; podaję za: L. Balter, Pneumatologia ..., s. 78.

${ }^{33}$ Por. L. Balter, Pneumatologia ..., s. 79. Sergiusz Bułgakow określa Ją jako „Nosicielkę Ducha Świętego” („Duchonosica”). Por. A. Skwarczyński, Duch Święty a Maryja w ujęciu Sergiusza Bułgakowa i św. Maksymiliana Kolbego, Niepokalanów 1995, s. 9.

${ }^{34}$ M. Kolbe pisał, że co prawda Trzecia Osoba Boska nie jest wcielona, jednak w pewnym sensie można powiedzieć, że Niepokalana jest wcieleniem Ducha Przenajświętszego. Por. M. Kolbe, Wykład z 5 lutego 1941, [w:] Konferencje Świętego Maksymiliana Marii Kolbego, Niepokalanów 1990, s. 428.

${ }^{35}$ Por. M. Kolbe, Fragment niedokończonej książki, [w:] Konferencje Świętego Maksymiliana Marii Kolbego, Niepokalanów 1990, s. 598.

${ }^{36}$ Por. A. Skwarczyński, Duch Święty a Maryja..., s. 8.

${ }^{37}$ Por. tamże, s. 9.

${ }^{38}$ Por. K. Stehlin, Kim jesteś o Niepokalana?, Warszawa 2007, przypis 53, s. 53. Maryja stanowi święte naczynie Ducha Świętego, gdyż Jej ludzka osoba jest całkowicie przezroczysta na Jego działanie. Sergiusz Bułgakow pisał, że naprawdę nie można mówić o wcieleniu Trzeciej Osoby Trójcy, ale o Jej objawieniu w ludzkiej postaci. Por. S. Bułgakow, Ikona ..., s. 91.

${ }^{39}$ Por. L. Balter, Pneumatologia..., s. 78.

${ }^{40}$ Por. P. Evdokimov, Panagion et Panagia, „Etudes Mariales” 27 : 1970, s. 59-71; podaję za:

L. Balter, Pneumatologia ..., s. 76-78.

${ }^{41}$ Por. L. Balter, Pneumatologia ..., s. 78.

${ }^{42}$ Por. A. Skwarczyński, Duch Święty a Maryja..., s. 5; Trzecia Osoba Trójcy to Niepokalane Poczęcie wiążące Ojca i Syna. Por. K. Stehlin, Kim jesteś o Niepokalana?, s. 54.

${ }^{43}$ Por. L. Balter, Pneumahagijny charakter kultu maryjnego, [w:] Człowiek we wspólnocie Kościoła, red. L. Balter, Warszawa 1979, s. 436-448. 
Maksymilian Kolbe nazywa Trzecią Osobę Bogiem-Miłością, który poprzez zewnętrzny znak okazuje swoje pośrednictwo u Ojca i Syna. Tym zewnętrznym znakiem jest właśnie Bogurodzica ${ }^{44}$. Istnieje związek między Duchem Świętym a Bogurodzicą, gdyż Trzecia Osoba Trójcy posiada w sobie pierwiastek żeński, a Kolbe używał nawet określenia „Duch miłości matczynej”45. Trzecia Hipostaza Trójcy mogła objawić się w pełni chwały tylko w hipostazie stworzonej, dzięki czemu zostaje przezwyciężona Jej kenoza, czyli wyniszczenie ${ }^{46}$. Chociaż nie istnieje bezpośrednie wyobrażenie Trzeciej Osoby Trójcy Świętej, to jednak uznaje się, że Jej ukrytą ikoną pod ludzką postacią jest właśnie Theotokos ${ }^{47}$. Bogurodzica w widzialny sposób Ją uobecnia, stanowiąc zatem Jej odbicie, czyli prawdziwą ikonę. Z obrazem Ducha Świętego mamy do czynienia szczególnie wtedy, gdy Bogurodzica ukazywana jest bez Dzieciątka ${ }^{48}$. Ikony przedstawiające Maryję stały się na Rusi nawet bardziej popularne niż wyobrażenia samego Chrystusa m.in. z tego powodu, że była Ona bardziej dostępna dla duszy zwykłego człowieka ${ }^{49}$. Można śmiało stwierdzić, że przedstawienia tego typu zawsze są pneumatologiczne.

\section{Ikona Zwiastowania Maryi}

Ikona Zwiastowania Matce Bożej (gr. Ewangelismos, ros. Błagowieszczenije Prieswiatoj Bogorodicy) ${ }^{50}$ chociaż przedstawia konkretną scenę z życia Maryi, to jednak posiada uniwersalną i kosmiczną symbolikę ${ }^{51}$. Kosmiczny aspekt wynika również z faktu, że święto Zwiastowania wiąże się z okresem wiosennego zrównania dnia z nocą ${ }^{52}$, czyli momentu, gdy przyroda budzi się do życia, a stworzenie odradza się. W scenie Zwiastowania podkreślono również duchowe odrodzenie, bo wówczas ludzkie stworzenie reprezentowane przez Maryję przyjęło w całej pełni wolę Boga. Ponieważ mariologia zawsze związana jest z pneumatologią, także i na ikonie ma to swoje odzwierciedlenie. Zresztą Duch Święty zawsze kojarzony był z wewnętrznym przebudzeniem i odnową. Jest On nie tylko Pocieszycielem,

${ }^{44}$ Por. Wybór pism bł. Maksymiliana Marii Kolbego, 583, Warszawa 1973; podaję za: A. Skwarczyński, Duch Święty a Maryja..., s. 5.

${ }^{45}$ A. Skwarczyński, Duch Święty a Maryja..., s. 5.

${ }^{46}$ Bułgakow szukał takiej hipostazy stworzonej, w której mógłby się objawić Duch Święty. Zresztą osobę w całkowitej pełni może przestawić tylko osoba-hipostaza. Bułgakow nie mówi o kenozie Ducha Świętego w samej Bogurodzicy, gdyż stanowi Ona najpełniejsze objawienie Ducha Świętego. Por. A. Skwarczyński, Duch Święty a Maryja ..., przyp. 11, s. 5, s. 13.

${ }^{47}$ Por. S. Bułgakow, Ikona..., s. 85.

${ }^{48}$ Por. tamże, s. 91.

${ }^{49}$ Por. I. Jazykowa, Świat ikony, thum. H. Paprocki, Warszawa 1998, s. 111.

${ }^{50}$ Por. E. Smykowska, Ikona. Mały stownik, Warszawa 2008, s. 94.

${ }^{51} \mathrm{Na}$ temat ikony Zwiastowania por. K. Klauza, Ikona Zwiastowania. Medytacje, Warszawa 2001.

${ }^{52}$ Por. P. Florenski, Kosmiczna symbolika ikony Zwiastowania Najświętszej Marii Panny, [w:] P. Florenski, Ikonostas i inne szkice, Warszawa 1984, s. 68. 
ale także Duchem ofiarującym życie i inicjującym początek jakiegoś bytu oraz Objawem Miłości Boga ${ }^{53}$.

Obok głównego tematu uwypuklona jest tu rola Trzeciej Osoby Trójcy poprzez zastosowanie określonego schematu ikonograficznego. Wielokrotnie w centrum ukazywano Maryję, która podczas wizyty anioła zajęta jest pracą. W lewej ręce trzyma Ona krwistoczerwony motek przędzy, z którego wysuwa się pasemko czerwonej nici i kieruje się ku prawej dłoni. W ten sposób rozciągnięta nić w postaci ognistoczerwonej linii przechodzi przez całe ciało Maryi, jak gdyby przecinając Jej łono, co symbolizuje boskość i oznacza, iż w Niej za sprawą Ducha Świętego począł się Syn Boży ${ }^{54}$. Na wielu ikonach na samej górze kompozycji umieszcza się fragment nieba w formie półokręgu, z którego wyłaniają się promienie oznaczające działanie samego Ducha Świętego. Maryja zaś wznosi wzrok ku górze, ku tym promieniom, co oznacza, iż w zupełności przyjmuje wolę Boga ${ }^{55}$. W tego typu przedstawieniach Duch Święty może też przybierać postać gołębicy, która wzlatuje ku górze ponad głową Oblubienicy. Gołębica występuje przeważnie na tle koła wydzielonego z tła, co świadczy o tym, że mamy tutaj do czynienia z Osobą Boską ${ }^{56}$.

\section{Orantka}

Na uwagę zasługuje tutaj typ ikonograficzny „Znak”, ukazujący Matkę Bożą przyjmującą postawę Orantki ${ }^{57}$. Na tle Jej ciała unosi się medalion z wizerunkiem Emmanuela, co stanowi symboliczne wyobrażenie łona Matki, w którym za sprawą Ducha Świętego począł się Bóg-człowiek ${ }^{58}$.

Charakterystyczna jest tutaj ikona „Orantki” jarosławskiej, gdzie szaty Bożej Matki są pokryte złotą asystką, wyraźnie wskazującą na łaskę Ducha Świętego, która w trakcie poczęcia obficie wylała się na służebnicę Pańską ${ }^{59}$. Widać więc, że podkreślono tu obecność Trzeciej Osoby Trójcy w specyficzny sposób. Nie jest Ona ukazana osobowo, ani nawet pod postacią gołębicy czy promieni, lecz Jej działanie zasygnalizowano kolorem - światłem, a w tym wypadku złotem. Theotokos ukazana została jako całkowicie przeniknięta Duchem Świętym, który

${ }^{53}$ Por. P. Evdomimov, Sztuka ikony..., s. 212.

${ }^{54}$ Por. J. Forest, Modlitwa z ikonami, tłum. E. Nowakowska, Bydgoszcz 1999, s. 99. Istnieje również thumaczenie teologiczne, według którego za pomocą nici Maryja tka obraz, czyli tworzy namacalne ciało dla Słowa Bożego. Jaskrawa czerwień kłębka wskazuje na boskość Tego, który ma się narodzić. Por. T. Špidlik, M. I. Rupnik, Mowa obrazów, tłum. J. Dembska, Warszawa 2001, s. 82-83.

${ }^{55}$ Por. E. Smykowska, Ikona..., s. 94.

${ }^{56}$ Por. L. Balter, Pneumatologia..., s. 86.

${ }^{57}$ Łac. orans - „modląca się”. Por. E. Smykowska, Ikona..., s. 59.

${ }^{58}$ Por. I. Jazykowa, Świat ikony, s. 112; Maryja przyjęła Syna Bożego najpierw w swoim sercu, a potem dopiero w ciele (,prius in mente, quam in corpore”). Duchowe poczęcie Syna Bożego (Słowa) w Duchu Świętym jest właśnie źródłem unii hipostatycznej Drugiej Osoby Trójcy i ciała ludzkiego. Por. K. Stehlin, Kim jesteś o Niepokalana?, s. 55.

${ }^{59}$ Por. I. Jazykowa, Świat ikony, s. 113. 
posłużył się Nią jako materiałem podczas Wcielenia Chrystusa. Uznać więc należy, że Duch Święty stanowi bezpośrednią przyczynę, a Maryja macierzyńską przyczynę utworzenia się ludzkiego ciała Syna Bożego ${ }^{60}$.

\section{Duch Święty na ikonach wyobrażających Chrystusa}

Syn Boży jest obrazem i ucieleśnieniem Ojca „w Duchu”61. Oczywiście nie można tu powiedzieć, że Chrystus obrazuje Ducha Świętego, tak jak to było w przypadku Maryi, lecz prezentuje On tylko i wyłącznie siebie samego, czyli Drugą Osobę Trójcy $^{62}$, ale często na obrazach towarzyszy Mu Duch Święty, który nigdy nie występuje sam.

\section{Ikona Narodzenia Chrystusa}

Na ikonie Narodzenia Chrystusa (gr. He Genesis, ros. Rożdiestwo Christowo) ${ }^{63}$, w górnej części kompozycji na osi, nad główną sceną wydzielona została niewielka półkolista sfera nieba. Z jej centrum wyłania się i kieruje na dół jeden grubszy promień, który gdy schodzi niżej, rozgałęzia się na trzy węższe promienie. Ma to podkreślać obecność w zbawczym wydarzeniu całej Trójcy ${ }^{64}$. Wewnątrz tego zstępującego świetlistego promienia znajduje się małe koło symbolizujące Ducha Świętego ${ }^{65}$. Widać wobec tego, że Trzecia Osoba Trójcy znajduje się pomiędzy Ojcem symbolizowanym przez strefę nieba a Synem Bożym leżącym w żłobie w niższej części kompozycji. Wyraźnie widać tu odwołanie do credo, gdzie napisano, że Jezus Chrystus: ,przyjął ciało za sprawą Ducha Świętego z Maryi Dziewicy i stał się człowiekiem"66. Wobec tego unia hipostatyczna w Chrystusie to dzieło zarówno Bogurodzicy, jak i Ducha Świętego ${ }^{67}$.

\section{Ikona Chrztu Chrystusa}

Chrystus, przyjmując jako własne ludzkie ciało, ogołocił samego siebie ${ }^{68}$, dlatego nieodzowne stało się dla Niego nieustanne towarzystwo i opieka Ducha

${ }^{60}$ Por. K. Stehlin, Kim jesteś o Niepokalana?, s. 55.

${ }^{61}$ Por. F. X. Durwell, Ojciec Bóg w swoim misterium, Kielce 2000, s. 18n; podaję za: L. Balter, Pneumatologia..., s. 76.

${ }^{62}$ Por. L. Balter, Pneumatologia..., s. 82.

${ }^{63}$ Por. E. Smykowska, Ikona..., s. 53.

${ }^{64}$ Por. M. Janocha, Ikonografia świąt Pańskich, [w:] Chrystus wybawiający..., s. 229; E. Smykowska, Ikona..., s. 54.

${ }^{65}$ Por. J. Forest, Modlitwa z ikonami, s. 105; P. Evdokimov, Sztuka ikony..., s. 226.

${ }^{66}$ Sobór Konstantynopolitański I (381), Wyznanie wiary 150 Ojców, s. 68: „et nostram salutem descendtit et incarnatus est de spiritu sancto et Maria virgine humanatus est”.

${ }^{67}$ Por. K. Stehlin, Kim jesteś o Niepokalana?, s. 55.

${ }^{68} \mathrm{Fp}$ 2, 7: „lecz ogołocił samego siebie, przyjąwszy postać sługi, staszy się podobnym do ludzi. A w zewnętrznym przejawie uznany za człowieka”. 
Świętego ${ }^{69}$. Niemniej jednak przed oczami ludzi dopiero podczas chrztu Janowego w Jordanie Duch Święty objawił się w widzialny sposób. Duch ten, unoszący się nad rzeką Jordan, jest tym samym, który został opisany w Księdze Rodzaju jako unoszący się nad wodami i przekazujący życie. Również i teraz przyczynia się do powstania nowego bytu ${ }^{70}$.

Na ikonie Chrztu Chrystusa (gr. Babtesis, ros. Kreszczenije Jisusa Christa) ${ }^{71}$ mamy tu do czynienia z teofanią gr. Epifania, ros. Bogojawljenije), czyli objawieniem się całego Trójosobowego Boga ${ }^{72}$. Od momentu chrztu dokonanego przez Jana Prodromosa Chrystus jest Namaszczony Duchem Świętym, a Ojciec ma w Nim upodobanie (por. Mt 3,17). To „upodobanie” to upostaciowiona miłość między Ojcem i Synem, czyli zstępująca Trzecia Hipostaza Trójosobowego Boga ${ }^{73}$.

Podczas gdy Bóg Ojciec objawił się jako głos ${ }^{74}$, Syn Boży w samym Jezusie Chrystusie $^{75}$, to trzecia Hipostaza Trójcy objawiła się w postaci gołębicy, o czym świadczą relacje zawarte w Ewangeliach: „A gdy Jezus został ochrzczony, natychmiast wyszedł z wody. A oto otworzyły Mu się niebiosa i ujrzał Ducha Bożego zstępującego jak gołębicę, i przychodzącego na Niego” (Mt 3, 16) ${ }^{76}$; „Duch Święty zstąpił na Niego, w postaci cielesnej niby gołębica” (Łk 3, 22); ,Jan dał takie świadectwo: «Ujrzałem Ducha, który jak gołębica zstępował z nieba i spoczął na Nim»" (J 1, 32) ${ }^{77}$.

Podkreślono też rolę Ducha Świętego jako Tego, który objawia człowieczeństwo Syna Ojcu, a Ojca Synowi ${ }^{78}$. Ikona ta wykazuje podobieństwo do przedstawienia Narodzin Chrystusa. Również i w tym wypadku mamy do czynienia z kręgiem nieba na górze kompozycji i ze zstępującym z niego promieniem oznaczającym boskość. Duch Święty ukazany jest pod postacią gołębicy i może być umieszczony w małym okręgu wewnątrz grubego promienia ${ }^{79}$. Można uznać, że promienie światła są właśnie Jego atrybutem ${ }^{80}$.

${ }^{69}$ Por. L. Balter, Pneumatologia..., s. 82.

${ }^{70}$ Por. P. Evdokimov, Sztuka ikony..., s. 245.

${ }^{71}$ Por. M. Janocha, Ikonografia..., s. 233.

${ }^{72}$ Por. E. Smykowska, Ikona..., s. 16. Por. K. Onasch, A. Schnieper, Ikony. Fakty i legendy, thum. Z. Szanter, M. Smoliński, Warszawa 2002, s. 107; J. Forest, Modlitwa z ikonami, s. 107n.

${ }^{73}$ Por. P. Evdokimov, Sztuka ikony..., s. 240.

${ }^{74}$ Mt 3, 17: „Et ecce vox de caelis dicens: Hic est Filius meus dilectus, in quo mihi complacui”; podaję za: Biblia Sacra juxta Vulgatum Clementam. Editio electronica. Plurimis consultis editionibus diligenter praeparata a Michaele Tvveedale, Londini MMV.

${ }^{75} \mathrm{~J}$ 1, 34: „Et ego vidit: et testimonium perhibui quia hic est Filius Dei”.

${ }^{76}$ Mt 3, 16: „Babtizatus autem Jesus, confestim ascendit de aqua, et ecce aperti sunt ei aeli: et vidit Spiritus Dei descendentem sicut columbam, et venientem super se".

77 J 1, 32: „Et testimonium perhibuit Johannes, dicens: Quia vidi Spiritus descendentem quasi columbam de celo, et mansit super eum".

${ }^{78}$ Por. P. Evdokimov, Sztuka ikony..., s. 239.

${ }^{79}$ Por. J. Forest, Modlitwa z ikonami, s. 108.

${ }^{80}$ Por. P. Evdokimov, Sztuka ikony..., s. 244. 


\section{Ikona Przemienienia Pańskiego}

$\mathrm{Na}$ ikonie tej co prawda ukazane jest przemienienie samego Chrystusa (gr. Metamorfosis, ros. Prieobrażenije Gospodnie) ${ }^{81}$, niemniej mamy też tu do czynienia z objawieniem się całej Trójcy. Widoczne jest również działanie Ducha Świętego ukazującego się pod postacią świetlistego obłoku ${ }^{82}$. Ta świetlistość przenikająca całą ikonę świadczy o Jego obecności w całym wydarzeniu. Apostołowie zaś dzięki przemienieniu właśnie przez Niego mogli zobaczyć Boga ${ }^{83}$. Światło na tej ikonie stworzone jest przez okrągłą mandorlę, otaczającą postać Chrystusa, wewnątrz której znajduje się gwiazda ${ }^{84}$. Wszystko to wskazuje na transcendentne energie boskie oraz Trzecią Hipostazę Boską.

Na taki sposób przedstawiania miała wpływ myśl hezychastyczna rozwinięta w XIV wieku przez Grzegorza Palamasa. Według palamizmu Duch Święty może występować zarówno jako Osoba, jak też jako niestworzona energia. Ta Boska energia co prawda objawia się na zewnątrz w Synu Bożym, ale tak naprawdę przekazana jest w Duchu Świętym ${ }^{85}$.

\section{Ikona Wniebowstąpienia}

Chrystus przed swoim Wniebowstąpieniem obiecał apostołom przyjście Ducha Świętego, kierując do nich słowa: „Pożyteczne jest dla was moje odejście. Bo jeżeli nie odejdę, Pocieszyciel nie przyjdzie do was. A jeżeli odejdę, poślę Go do was” (J 16, 7).

W czasie Wniebowstąpienia poprzez swoje błogosławieństwo zapowiada On mającą nastąpić w przyszłości Pięćdziesiątnicę, kiedy dojdzie do zesłania Ducha Świętego. Chrystus obiecuje uczniom, że będzie prosił Ojca, aby przysłał im innego Pocieszyciela (por. J 14, 16). Na ikonie ilustrującej Wniebowstąpienie Pańskie (gr. Analepsis, ros. Wozniesienije Gospodnie) ${ }^{86}$ mamy więc do czynienia z epiklezą Pięćdziesiątnicy ${ }^{87}$.

Gest błogosławieństwa wykonywany przez Chrystusa traktowany jest jako źródło łaski. Związane jest to z niewidzialną obecnością i działaniem Ducha Świętego w Kościele reprezentowanym tutaj przez Bogurodzicę i apostołów ${ }^{88}$.

Na ikonie niekiedy podkreślano obecność Ducha Świętego i wówczas ukazywano Go pod postacią gołębicy na centralnej osi kompozycji między wstępującym do nieba

${ }^{81}$ Por. E. Smykowska, Ikona..., s. 66.

${ }^{82}$ Por. J. Forest, Modlitwa z ikonami, s. 115.

${ }^{83}$ Por. P. Evdokimov, Sztuka ikony..., s. 251.

${ }^{84}$ Por. tamże, s. 253; jednak na wielu ikonach wnętrze mandorli jest ciemne, co świadczy o wpływach myśli hezychastycznej. W ten sposób „Przemienienie” namalowali Teofanes i Rublow. Por. I. Jazykowa, Świat ikony, s. 136.

${ }^{85}$ Por. P. Evdokimov, Sztuka ikony..., s. 288.

${ }^{86}$ Por. E. Smykowska, Ikona..., s. 86.

${ }^{87}$ Por. P. Evdokimov, Sztuka ikony..., s. 272.

${ }^{88}$ Por. E. Smykowska, Ikona ..., s. 87. 
Chrystusem a dolną grupą postaci, będących świadkami tego wydarzenia. Świadczy to o tym, że Chrystus, udając się do domu swego Ojca, przekazał powstającemu Kościołowi Ducha, który po Wniebowstąpieniu kontynuuje zbawczą ekonomię w sposób rzeczywisty ${ }^{89}$.

\section{Ikona zesłania Ducha Świętego}

Przed swoim Wniebowstąpieniem Chrystus zapowiedział uczniom, że Duch Święty zstąpi na nich, dzięki czemu w pełni Go poznają i staną się Jego świadkami ${ }^{90}$. Syn Boży po zakończeniu swojej misji na ziemi powrócił do Ojca, którego prosi o Ducha dla ludzi, przygotowuje więc miejsce Duchowi mającemu wkroczyć w historię ludzkości. Ojciec, tak jak kiedyś posłał na ziemię Syna, tak teraz posyła Ducha Świętego podczas Pięćdziesiątnicy. Zesłanie Ducha stanowi kolejne działanie podejmowane ze strony Ojca, by dokończyć swój plan zbawienia ${ }^{91}$. I rzeczywiście, gdy apostołowie i kuzyni Jezusa zebrali się w Wieczerniku, podczas modlitwy zstąpił na nich Duch Święty. Wydarzenie to, które nastąpiło w pięćdziesiąty dzień po Zmartwychwstaniu Chrystusa, czyli w „Pięćdziesiątnicę” (gr. pentekostos) ${ }^{92}$, zostało opisane w Dziejach Apostolskich:

Nagle dał się słyszeć z nieba szum, jakby uderzenie gwałtownego wiatru, i napełnił cały dom, w którym przebywali. Ukazały im się też języki jakby z ognia, które się rozdzieliły, i na każdym z nich spoczął jeden. I wszyscy zostali napełnieni Duchem Świętym, i zaczęli mówić obcymi językami, tak jak im Duch pozwalał mówić (Dz 2, 1-4).

Na ikonie przedstawiającej Zesłanie Ducha Świętego (gr. Pentekoste, ros. Soszestwije Swiatogo Ducha $)^{93}$ centrum kompozycji zajmuje kolegium dwunastu apostołów siedzących przy długiej, półokrągłej ławie. Pośród nich znajduje się puste miejsce, na którym niegdyś zasiadał sam Chrystus, teraz jednak jest On niewidoczny, ale nadal pozostaje obecny w Kościele ${ }^{94}$.

Niekiedy na tym właśnie miejscu malowano Bogurodzicę, lecz zazwyczaj w ogóle nie umieszczano Jej na tej ikonie. Tłumaczy się to tym, że Maryja posiadała już pełnię Ducha, który zstąpił na Nią wcześniej, bo przy Zwiastowaniu, i była Ona z Nim w pełni zjednoczona ${ }^{95}$. Właśnie dlatego, że wcześniej otrzymała dary Ducha, stanowiła figurę przyszłego Kościoła. Apostołowie zaś symbolizują Kościół przyjmujący dary Ducha Świętego. Ponieważ Bogurodzica jest również figurą

${ }^{89}$ Por. L. Balter, Pneumatologia..., s. 82.

${ }^{90}$ Por. J. Forest, Modlitwa z ikonami, s. 142; „Pożyteczne jest dla was moje odejście. Bo jeżeli nie odejdę, Pocieszyciel nie przyjdzie do was. A jeżeli odejdę, poślę Go do was. On doprowadzi was do pełnej prawdy" (J 16, 7. 13).

${ }^{91}$ Por. P. Evdokimov, Sztuka ikony..., s. 277; L. Balter, Pneumatologia ..., s. 87.

${ }^{92}$ Por. J. Forest, Modlitwa z ikonami, s. 143.

${ }^{93}$ Por. E. Smykowska, Ikona..., s. 92.

${ }^{94}$ Por. J. Forest, Modlitwa z ikonami, s. 143.

${ }^{95}$ Por. tamże. 
Kościoła, byłaby wobec tego tylko jego powtórzeniem na tym przedstawieniu, a takie dublowanie jest niepotrzebne ${ }^{96}$.

Natomiast według Maksymiliana Kolbego i Sergiusza Bułgakowa w czasie Pięćdziesiątnicy Trzecia Osoba Boska zstąpiła początkowo na Bogurodzicę, a dopiero „przez” Nią promieniowała na apostołów ${ }^{97}$.

Na samej górze kompozycji umieszczona jest półkolista sfera wyobrażająca część nieba. $Z$ tego niepełnego okręgu wyłaniają się promienie lub też języki ognia. Rozdzieliły się one w ten sposób, że każdy z promieni znajduje się nad jednym apostołem. Ma to wskazywać na fakt, iż wszystkie osoby zostały ochrzczone Duchem Świętym, który działa w nich na sposób indywidualny ${ }^{98}$. Dwanaście promieni symbolizuje również pełnię Ducha, który zamieszkuje także w pustej przestrzeni pośród apostołów, zjednoczonych we wspólnocie ${ }^{99}$. Na ikonie podkreślono więc jedność panującą w Kościele, która jest skutkiem działania Ducha Świętego. Apostołowie przemienili się i otrzymali nowe życie, dlatego nie odczuwa się tu gwałtownego szumu wiatru, lecz spokój, ciszę i wewnętrzne skupienie zebranych osób ${ }^{100}$.

Ojciec, spełniając prośbę Syna, posyła Ducha i kieruje się nie tylko na jednego wybranego człowieka, ale ku wszystkim ludziom pod postacią języków ognia. Są one postacią boskiej energii, przenikającej i dającej życie wszystkim stworzeniom ${ }^{101}$ oraz przemieniającej cały kosmos ${ }^{102}$. Niekiedy z kolistej sfery może wychodzić tylko jeden dłuższy promień oznaczający właśnie Trzecią Hipostazę Trójcy ${ }^{103}$.

Podczas Pięćdziesiątnicy doszło do samoobjawienia się Trójosobowego Boga, którego prawdziwe uwielbienie możliwe jest właśnie dzięki Parakletowi ${ }^{104}$. Jest On tak naprawdę drugim Pocieszycielem, innym od Syna Bożego, posłanym co prawda na prośbę Syna, ale nie podporządkowanym $\mathrm{Mu}^{105}$.

${ }^{96} \mathrm{Na}$ Wschodzie za słuszne uznano ukazywanie Maryi na ikonie Wniebowstąpienia, chociaż tak naprawdę nie była Ona obecna podczas tego wydarzenia. W tym wypadku oznaczała Ona Kościół przyjmujący zapowiedź Chrystusa odnośnie do zesłania Ducha Świętego. Natomiast na ikonie Pięćdziesiątnicy pomijano postać Bogurodzicy. Por. P. Evdokimov, Sztuka ikony..., s. 280; podaję za: L. Balter, Pneumatologia ..., s. 88.

${ }^{97}$ Por. A. Skwarczyński, Duch Święty a Maryja..., s. 17.

${ }^{98}$ Por. J. Forest, Modlitwa z ikonami, s. 144; P. Evdokimov, Sztuka ikony..., s. 278.

${ }^{99}$ Por. H. M. J. Noumen, Ujrzeć piękno Pana, modląc sięz ikonami, thum. J. Węcławik, Warszawa 1998, s. 63-64.

${ }^{100}$ Por. J. Forest, Modlitwa z ikonami, s. 141.

${ }^{101}$ Por. P. Evdokimov, Sztuka ikony..., s. 278.

${ }^{102}$ Por. tamże, s. 280.

${ }^{103}$ Por. J. Forest, Modlitwa z ikonami, s. 144.

${ }^{104}$ Por. P. Evdokimov, Sztuka ikony..., s. 277.

${ }^{105}$ Por. L. Balter, Pneumatologia..., s. 87; P. Evdokimov, Sztuka ikony..., s. 277. 
Ojcowie Kościoła podkreślali wielką rolę Trzeciej Osoby Trójcy Świętej, co najpierw przejawiło się w ustaleniu dogmatu trynitarnego, a następnie stało się widoczne w sztukach plastycznych.

W pismach ojców Kościoła Duch Święty był różnie określany, uważano Go za wieczną Radość panującą między Ojcem a Synem oraz ofiarującą życie ${ }^{106}$. Traktowano Go jako życie Boże nieustannie działające oraz hipostatyczną (czyli upostaciowioną) miłość między Pierwszą i Drugą Osobą Boską ${ }^{107}$. Wewnątrz Trójcy to właśnie On pełni rolę Bożej Agape $e^{108}$.

Chrystus tak naprawdę nie działał sam, lecz nieustannie towarzyszył Mu Duch Święty. Działalność Syna Bożego na ziemi była swego rodzaju wstępem dla przyszłego działania Trzeciej Osoby Trójcy Świętej, która zesłana podczas Pięćdziesiątnicy zwieńczyła całą zbawczą misję zgodnie z koncepcją boskiej ekonomii ${ }^{109}$.

Z całej Trójcy tylko Syn był obrazem wcielonym, stąd łatwo można Go było przedstawiać na wizerunkach jako człowieka. Natomiast Ojciec i Duch Święty nie posiadali obrazu wcielonego i dlatego istniały trudności w ukazywaniu ich w sztuce. Szczególnie dotyczyło to Trzeciej Osoby Trójcy, a wynikało to z faktu, że obrazem Ojca był Syn; obrazem Syna zaś Duch Święty, lecz nie było osoby, która byłaby obrazem Ducha Świętego. Z tego też względu Trzecia Hipostaza objawia się tylko i wyłącznie w swojej własnej epifanii ${ }^{110} \mathrm{i}$ występuje bądź jako gołębica, szum wiatru lub języki ognia.

Sama jednak stanowi „obraz Syna”, gdyż ukazuje Syna Ojcu. Co prawda to Syn jest prawdziwym obrazem Ojca, niemniej jednak trzeba dodać, że realność SłowaObrazu w całej Trójcy staje się możliwa właśnie poprzez Ducha Świętego, który zstępuje od Ojca na jedynego Syna. To właśnie w Duchu Świętym Ojciec i Syn stają się dla siebie naprawdę realni, stąd Trzecią Osobę można nazwać hipostatyczną realnością przenikającą całą Trójcę ${ }^{111}$. W sztukach plastycznych Duch Święty przybierał postać zwierzęcia (gołębicy) lub materii nieożywionej, a tylko na ikonie „Trójcy Starotestamentowej” ukazywany był jako anioł. Na Wschodzie nie malowano Go pod ludzką postacią, ale zdarzało się to na Zachodzie.

Wschodni ikonopisarze podkreślali działanie Ducha Świętego podczas procesu twórczego. Jego natchnienie staje się nieodzowne w sztuce ikonopisarskiej i jest On w sposób rzeczywisty Boskim Ikonografem ${ }^{112}$. Staje się On prawdziwym

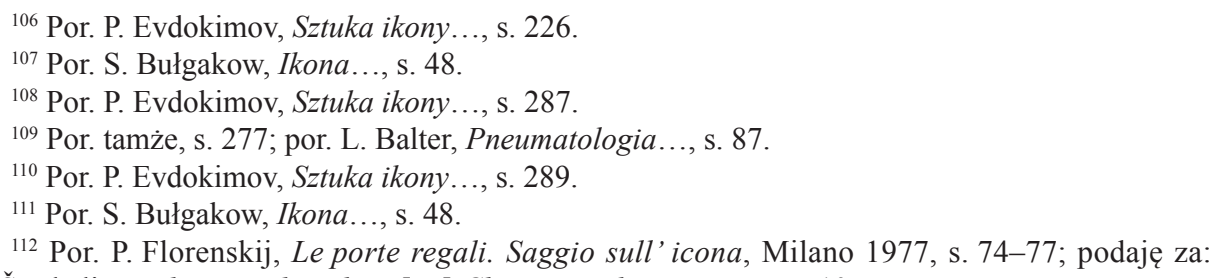
A. Štrukelj, Duchowe piękno ikon, [w:] Chrystus wybawiajacy..., s. 105. 
twórcą każdego dzieła wychodzącego spod ręki ikonografia i przez to uobecnia się na każdej ikonie ${ }^{113}$.

\section{Summary}

\section{Presentation of the Holy Spirit on Byzantine and Russian icons. The canon of iconographic and theological dogma}

The article describes how Christian art depicted in the Third Person of the Trinity. It was quide difficult, because the Holy Spirit could not appear as a man. Nevertheless, it can be concluded that the hidden remains an icon of the Holy Spirit, Mary, as a person completely penetrated him. On the third hypostasis of Marian icons also appeared as a dove further (the icon Annunciation), or as a light-gold.

Christ's presence on the perceptions of the Holy Spirit has been emphasized by showing the radius, or a small circle (the icon of Christ's birth). He revealed himself as a dove hovering (the icon of the Baptism of Christ), or as light (the icon of the Transfiguration).

However the icon showing a scene "Pentecost", he reveals himself tongues of fire descending figure, which rest upon the Apostles.

\section{Keywords}

Christianity, dogma, Holy Spirit, icon, Pentecost

${ }^{113}$ Por. L. Balter, Pneumatologia..., s. 90-91. 
